\title{
Introduction
}

\author{
Rodrigo Basco, Roger Stough and Lech Suwala
}

\section{Family Business and Regional Development}

Family business participation in economic activities has been a common phenomenon since pre-industrial societies, and its importance has evolved throughout time and across spatial contexts. These factors have often been neglected in family business and regional studies. Taking this research gap into account, this edited collection aims to deepen our understanding of the role family firms play in regional economies. Another objective is to recognise the effect of regional contexts on family firms by encouraging the cross-fertilisation of ideas, theories, and research methods between the two fields. In particular, our collection explores the relationship between families, firms, and regions and the extent to which these connections contribute to regional economic and social development. We therefore invite readers on this collective journey as we explore two seldom studied questions: (1) What role do family firms play in regional development? (2) How do different spatial regional contexts shape family firms' operations and performance?

The main rationale is to evaluate what we already know about the juxtaposition and cross-fertilisation between family business and regional studies. This will enable us to discover new lenses and research paths that can strengthen interdisciplinary methods and to envision and propose future lines of research. This edited collection intends to contribute to theory and practice by linking economic, social, and political players, whose interactions at local and regional levels are believed to play a role in their success.

Firstly, by unveiling the correlation between family business and regional studies, this volume explores the merging of families, firms, and regions from an interdisciplinary perspective at different levels of analysis (micro, meso, and macro levels). The connections between family and business have been extensively explored and studied and there is no doubt about the influence family has on firm decision-making. However, less is known about the intensity of these relationships across contexts, territories, and places. At the same time, regional studies have not recognised the role and importance of family firms as idiosyncratic economic and social players in regional development. Therefore, as an added value, this book addresses an 


\section{Rodrigo Basco et al.}

interdisciplinary view of the nexus between family firms and regions. By proposing new theoretical reasoning, this collection challenges existing theories to enlighten researchers, family businesses, and policymakers and help them understand and prepare for the phenomenon.

Secondly, this collection, which brings together researchers across family business studies, regional studies, and policymaking fields, is practical in nature. Connecting both theory and practice is our fundamental goal, so as to add value to our explorative and predictive research. Given that family firms are the most common organisational form around the world in developed, emerging, and transitional economies, our interests transcended basic research to include the sole interaction between family and business. In addition, we included the regional and spatial perspectives to unveil the role that family firms play in boosting or hindering local and regional socioeconomic development. From this perspective, research efforts undertaken here connect business families, family firms, regional developers and planners, and policymakers from both angles, to improve the world we live in. If this book can focus attention on the topic of family firms by initiating political debate at local, regional, national, and multinational levels, our initial goal will be accomplished.

This volume is organised into five segments to accommodate its interdisciplinary interpretation and to guide our readers in approaching the nexus of family business and regional studies. Part I ('Family Business and Regions') aims to introduce the topic of 'Family Business and Regional Development'. Chapter 1, by Basco and Suwala, introduces the discussion by examining theoretical fertile grounds between family business and regional studies. Research efforts are carefully approached in terms of both disciplines in the form of a literature review. This review explains and elaborates on the two most integrated models dealing with the nexus of family firms and regions and proposes future lines of research. In Chapter 2, Basco and Ricotta present quantitative exploratory research by analysing the persistence of family firms across European regions. In this chapter, the authors address two fundamental research questions: (1) Why are family firms unevenly distributed across regions, and to what extent is this related to the territories in which they exist? (2) Does the presence of family firms affect regional competitiveness, and if so, how and when?

Part II ('Micro-foundation channels') discloses the micro-foundations of the nexus between family businesses and regional development to our readers. In Chapter 3, Basco, Amato, Gómez-Anson, and Calabrò theorisefollowing the regional familiness approach and taking into account the fact that family business research is contextless - that family firms are more advantageous than their non-family counterparts when operating in small municipalities because of their emotional and social connections. The authors empirically demonstrate, in terms of productivity, that large urban settings are sources of diseconomies for Spanish family-managed firms. Hence, they are better suited to exploit highly embedded contexts such as 
small municipalities. In Chapter 4, Adjei and Eriksson explore the connection between family co-occurrence in firms and the relationship with firm performance in longitudinal quantitative research conducted in Sweden. They demonstrate that family co-occurrence in workplaces influences productivity and that the positive or negative impact of familial relationships on productivity is contingent on the type of family ties, members' skills, and the regional context. This section ends with Chapter 5, authored by Amato, Patuelli, and Lattanzi. This chapter, which draws on a sample of firms located in five different Italian industrial districts, suggests that family firms are more engaged in digital innovation than non-family firms. The authors justify their findings due to the stronger firm-specific family social capital and embeddedness in local district networks.

Part III ('Meso-foundation Channels') investigates family firms at the regional level by considering the connections activated and triggered by family firms to stimulate (or not) regional development. In Chapter 6, Lenz presents qualitative research that focuses on the regional disembedding process of family firms across generations. Exploring several Basque family firms in Spain, Lenz confirms that the differences between incumbents and successors in terms of personal characteristics, network connections, and beliefs on how to conduct business lead successors to experience weaker regional embedding than their predecessors. In Chapter 7, Amato, Backman, and Peltonen answer the question of whether family firms in Finland are more locally embedded than non-family ones. They conclude that firms in Finland rely greatly on enduring and spatially proximate stakeholders, and therefore indicate a stronger link with the socioeconomic milieu in which they dwell. This section concludes with Chapter 8, in which Graffenberger and Görmar present the role of hidden champions located in small towns in peripheral regions in Germany from a corporate responsibility perspective. The authors indicate that family firms' commitment to supporting corporate activities is higher than that of non-family firms because of familyrelated specificities and socio-emotional dimensions of local embeddedness.

Part IV ('Evidence around the World') presents three chapters on family business and regional development in the African, European, and Chinese contexts. In Chapter 9, Murithi and Woldesenbet explore the self-perception of family and non-family firms in terms of their contribution to regional development in Kenya. Because of the strategic behavioural differences between family and non-family firms, their contribution varies. In Chapter 10, Cappelli, Cucculelli, and Peruzzi further develop our understanding of the topic by analysing whether family firm density and industry scale affects entrepreneurship at regional level. Interestingly, the authors find that entrepreneurship reacts positively to the prevalence of family firms and negatively to the presence of large companies. However, these results only occur in Western European as opposed to Eastern European regions, in which entrepreneurial initiatives are driven significantly by the average firm size. Finally, in Chapter 11, Zhang, Dou, and Fang shed light on the connection 


\section{Rodrigo Basco et al.}

between family firms and regional development in China. This exploratory investigation exposes readers to the unique Chinese context to better understand the role of family firms in regions and, conversely, the effects of regional economic and development on family firms.

We conclude the edited collection with Part V ('A Policymaker Perspective') which provides a practical orientation to connect research and practice. Chapter 12, authored by Albers and Suwala, explores the link between family businesses and regional development from the spatial corporate responsibility lens in a German context. This practical view presents implications for urban and regional planning on how to perceive the role that family firms could play in regional development. Finally, in Chapter 13, Basco and Bartkevičiūtè present and explore the role of family firms in a place-based programme in Lithuania. The authors conclude that the local embeddedness of family members empower family firms to better utilise such place-based programme actions by reconfiguring existing regional resources, developing local social capital, and embracing a sense of regional belonging.

At this point, we would like to inform readers that our editor family shrank during the process of assembling chapters and reviewing manuscripts for this collection. Sadly, our esteemed colleague Roger Stough passed away in September 2019. During his exceptional academic career, Roger not only inspired us, but many other colleagues over the last five decades. He also produced numerous remarkable publications that later set the agenda for all disciplines. We are very honoured to have had the opportunity to work with this prestigious scholar and to form a mutual editorship with him on his probably last edited collection. Naturally, this volume is dedicated to Roger. 